\title{
Virus interference on local scale viticulture: the case of Moll variety from Majorca
} (Spain)

\author{
Enrico Cretazzo ${ }^{1,4^{*}}$, Carlos Padilla ${ }^{2}$, Josefina Bota ${ }^{3}$, Joan Rosselló ${ }^{1}$, Jaume Vadell ${ }^{1}$, Josep Cifre ${ }^{1}$
}

Universidad de las Islas Baleares/Grup de Recerca en Biologia de les Plantes en Condicions Mediterrànies - Cra. Valldemossa km 7.5 - 07122 - Palma de Mallorca - Spain. Instituto Murciano de Investigación y Desarrollo Agrario y Alimentario, Equipo de Virología - C/ Mayor s/n - 30150 La Alberca, Murcia - Spain.

${ }^{3}$ Institut de Recerca i Formació Agrària i Pesquera (IRFAP)/ Consejería de Agricultura, Medio Ambiente y Territorio, Gobierno de las Islas Baleares - C/. Eusebi Estaba $n^{\circ} 145$ 07009 Palma de Mallorca - Spain.

4Instituto de Investigación y Formación Agraria y Pesquera/ Consejeria de Agricultura, Pesca y Medio Ambiente, Junta de Andalucia - Cortijo de la Cruz s/n - 29140 - Churriana, Malaga - Spain.

*Corresponding author <enrico.cretazzo@juntadeandalucia.es>

Edited by: Daniel Scherer de Moura

Received June 27, 2012

Accepted October 29, 2012
ABSTRACT: In Europe, many autochthonous grapevines (Vitis vinifera L.) are only cultivated at local scale, but play a very important economic role due to their strict relation with terroir and wine tipicity. In this study, it was pursued to evaluate the influence of several factors on performance of Moll, the main autochthonous white variety of Majorca, by means of the database coming from a clonal preselection. The effects of multiple virus infections, vintage and vineyard components were studied by univariate linear models and principal component analysis, starting from measurement of production and must quality parameters of several vines located in 14 vineyards belonging to two appellations during four consecutive years (20012004). Absence of multiple virus infections, double cordon system, high clay content and Useful Water Reserve in soils have enhanced vine production without inducing considerable alterations in sugar accumulation in berries and acidity. Moll variety presented great viticultural and oenological potentials. Fertile and deep soils should be preferred in order to maximize production. Also, the use of certified propagation material is strongly recommended. However, further investigations are required to optimize must quality by opportune managements. This study does not provide only essential information to improve Moll cultivation in Majorca, but it also represents a useful example to analyze grapevine varieties that are endemically infected by viruses. In fact, in such situations, it may be supposed an insidious interference by viruses on terroir and wine tipicity.

Keywords: virus effects, autochthonous varieties, soil components, vintage, clonal preselection

\section{Introduction}

In old Europe, autochthonous local varieties are strongly related to vitivinicultural terroir and vine "tipicity", even though their role in quality vine is declining (Failla et al., 2007). In the last decade, in Spain, monovarietal wines obtained with local varieties started to have a great promotion among growers, especially in the case of whites (Campo et al., 2008). In Majorca $\left(39^{\circ} \mathrm{N} ; 1^{\circ} \mathrm{E}\right)$, Moll is the most important and cultivated white variety and its contribution to typical wine aroma is essential (Cretazzo et al., 2010b). The ascent of Moll occurred in the last 20 years. In fact, the boost of summer tourism in the island entailed an increased interest for white wines. In spite of that, until the beginnings of clonal selection in 2000, no rigorous scientific approach was undertaken in order to study this variety. Clonal selection is the main method to improve a wine grapevine (Vitis vinifera L.) variety (see Cretazzo et al., 2010b). Its main aim is to identify and propagate clones free of viruses that are listed in recognised certification programs. It includes an early step called "clonal preselection". Several vines located in different vineyards are evaluated during 4-5 years by measuring production and must quality parameters. Moll clonal preselection generated a big database (147 vines, 14 vineyards, 2 appellations, 4 vintages). In addition, exhaustive soil analyses were performed for each vineyard and more than $50 \%$ of vines were analyzed for the presence of the main grapevine viruses listed by certification programs.
In spite of terroir has been studied at many scales, by several experimental trial designs and focusing on different aspects depending on specific aims (review by Deloire et al., 2005), the main purpose was always to identify the most opportune geology, climate and vitivinicultural management (see Hancock, 1999) in order to obtain the best final product (wine). Therefore, the clonal preselection database used for this paper can also be suitable to perform a preliminary Moll terroir study.

\section{Materials and Methods}

Plant material - All 147 vines studied are located in selected vineyards for clonal preselection. Six vineyards belong to Binissalem-Mallorca appellation, while eight to Pla i Llevant appellation. In both appellations vineyards are included in a circular area with radius of less than $5 \mathrm{~km}$. The distance between the centres of these two hypothetic districts is almost $20 \mathrm{~km}$. The altitude of vineyards ranges from 100 to 150 m.a.s.l. with commonly East - West row orientation. More details about the clonal selection process in Majorca and the criterion for vine choice are described by Cretazzo et al. (2010b).

Production and quality parameters - All vines were evaluated during four consecutive years (2001-2004). Common parameters of a clonal selection were measured for each plant: Number of Cluster, Yield (g), Weight of 100 Berries (g), Sugar Content ( ${ }^{\circ}$ Brix), Titratable Acidity (g 
$\mathrm{L}^{-1}$ ), Pruning Weight (g), Index of Ravaz, Total Polyphenols Index and Total Tannins $\left(\mathrm{g} \mathrm{L}^{-1}\right)$. Methodologies have been detailed by Cretazzo et al. (2010a).

Soil analyses - In order to identify all horizons (layers) that were suitable for root activity, in each vineyard three representative pits were performed by using a backhoe. Each layer from each pit was sampled and analysed. The following parameters were evaluated: Percentage $(\mathrm{w} / \mathrm{w})$ of Clay, Loam and Sand in the soil fraction $<2$ $\mathrm{mm}$ by Robinson's pipette method according to Gee and Bauder (1986) and texture taxonomy by United States Department of Agriculture (USDA); Percentage of coarse elements with diameter $>2 \mathrm{~mm}(\Theta, \mathrm{w} / \mathrm{w})$; Soil moisture at Field Capacity (FC, \% w/w) and at Permanent Wilting Point (PWP, \% w/w) by comparing the weights of dry and wet soil under suction pressure of 0.3 and $1.5 \mathrm{MPa}$, respectively (according to Miller and Gardiner, 1998), using vacuum machines by Eijkelkamp Agrisearch Equipment BV (Giesbeek, Holland), after separating course elements; Bulk Density $\left(\rho, \mathrm{g} \mathrm{cm}^{-3}\right)$ by excavation method (according to Blake and Hartge, 1986) and Thickness $(\mathrm{H}, \mathrm{m})$; Useful Water Reserve (UWR, $\mathrm{mm}$ ) by calculation UWR $=(\text { FC-PWP })^{*}(100-\theta) * \mathrm{H}^{*} \rho ; \mathrm{pH}$ (ratio 1:2.5); Electric Conductivity (ratio $1: 5,25^{\circ} \mathrm{C}, \mathrm{dS} \mathrm{m}^{-1}$ ); Total Organic Matter (MOT, \% w/w) by determination of the Oxidable Organic Carbon (COO) (titration with iron sulphate $\left(\mathrm{FeSO}_{4}\right)$ of the excess of potassium dichromate $\left.\left(\mathrm{K}_{2} \mathrm{Cr}_{2} \mathrm{O}_{7}\right)\right)$ and calculation MOT $=$ COO*1.29*1.72 (being 1.29 and 1.72 the recuperation coefficient and the Van Bemmelen conversion coefficient, respectively) according to Porta et al. (1986); Total Nitrogen (\% w/w) following Kjeldahl digestion as described by Bremmer and Mulvaney (1986); Available Phosphorous (mg kg-1) according to Olsen method (1954); Total Carbonate (\% $\mathrm{w} / \mathrm{w})$ and Calcium Carbonate Equivalent (\% w/w) by reaction with hydrogen chloride $(\mathrm{HCl})$ and measurement of carbon dioxide $\left(\mathrm{CO}_{2}\right)$ according to the method of Bernard calcimeter as described by Porta et al. (1986); Exchangeable calcium $\left(\mathrm{Ca}^{++}, \mathrm{mmol} \mathrm{kg}{ }^{-1}\right)$, magnesium $\left(\mathrm{Mg}^{++}, \mathrm{mmol} \mathrm{kg}{ }^{-1}\right)$, potassium $\left(\mathrm{K}^{+}, \mathrm{mg} \mathrm{kg}^{-1}\right)$ and sodium $\left(\mathrm{Na}^{+}, \mathrm{mg} \mathrm{kg}^{-1}\right)$ by atomic absorption spectrophotometry as described by Rowell (1996); Cationic Exchange Capacity $\left(\mathrm{mmol} \mathrm{kg}^{-1}\right)$ by saturation with ammonium acetate $\left(\mathrm{CH}_{3} \mathrm{COONH}_{4}\right)$ (Bower et al., 1952).

In order to assign unique values to each vineyard, a weighted average was calculated for each parameter considering the values of the different soil horizons identified. For Useful Water Reserve it was considered the sum of the different layers.

Weather data - The Balearic Island $\left(39^{\circ} \mathrm{N} ; 1^{\circ} \mathrm{E}\right)$ territorial delegation of the "Agencia Estatal de Metereología" (AEMET) provided monthly weather data relative to 2001-2004 seasons. Potential Evapotranspiration (mm) and Temperature $\left({ }^{\circ} \mathrm{C}\right)$ were measured using two thermometric stations (one per appellation), while rainfall (mm) using four pluviometric stations (two per appellation).
Virus analyses - Infections by Grapevine leafroll virus 1 and 3 (G1RaV-1 and GLRaV-3), Grapevine fanleaf virus (GFLV) and Grapevine fleck virus (GFkV) were assessed in 2005 by Enzyme-Linked Immuno-Sorbent Assay (ELISA). These are the only viruses listed by legislation for grapevine certification and the most economically important in Majorca (Cretazzo et al., 2010a). In order to confirm results, for both negative and doubtful samples, the tests were replicated in the same year and, if necessary, repeated and replicated in 2006 (see Cretazzo et al. $2010 \mathrm{~b})$. The tests were performed on 76 vines located in 12 vineyards.

Discriminating vineyard characteristics - Although a standardization of cultural management was pursued (Cretazzo et al., 2010a), vineyards revealed some intrinsic differences that can influence performance, such as: rootstock, age of vineyard and Training System. The only two rootstocks used for Moll are 110 Richter and 16149. The Training Systems in use are double permanent cordon, low vase (height of trunk $=0.3-0.4 \mathrm{~m}$ ) and high vase (height of trunk $=0.8-0.9 \mathrm{~m}$ ). Three age groups were proposed: 20-35 years, 35-50 years and more than 50 years. The planting density ranges from 2700 to 3000 vines/ha. Regardless of Training System, all vines were pruned to obtain 12 shoots (two shoots per spur), allowing no more than two clusters per shoot. The vineyards Bi15 and Bi15a (Table 5) are located in the same farm but they differ in vineyard age and Training System.

Statistical analyses - The influence of many factors on production and must quality parameters was evaluated by means of ANOVAs and univariate analyses of variance. The effects of both a factor and the interaction of more than one on a parameter were considered significant when $p<0.05$. In order to underline clear relations, from total database coming from the clonal preselection, four year data, minor sets of data were extracted and called models: three year data (excluding 2002, see Result and Discussion), four year data only for vines tested by ELISA and three year data only for vines tested by ELISA. A principal component analysis was performed on vine parameter data. The softwares used were SPSS 17.0 (SPSS Corporation, Chicago, IL, USA) for calculations and SigmaPlot 8.0 (Systat Software Inc., San Jose, CA, USA) for graphics.

\section{Results and Discussion}

Basic Terroir Units (BTUs) for Moll: an interesting aspect - Environmental conditions indicated uniformity between appellations (Table 1). In a previous study, factor appellation showed much lower influence on vine parameters than both vintage and vineyard (Cretazzo et al., 2007). In addition, Moll phenology did not show consistent differences between appellations (Medrano $\mathrm{H}$., 2004, data not published). Thus, based on a classification criteria proposed by Smart (1985), it can be said that 
both appellations are under the same macro and mesoclimate conditions. On the other hand, it is not easy to distinguish more than one geological state in the entire area studied. All vineyard soils have developed on parent rocks which consist of a combination between marl limestone from the Cretaceous and hard limestone from the Jurassic; quaternary sediments coming from the erosion of neighboring mountains and hills have been accumulating above this matrix in time (Farrús et al., 2002). In well-maintained soils, parent rocks produce small direct effects on grape parameters (Huggett, 2006). So, for Moll, it is possible that geological contribution to terroir (White et al., 2007) should be focused on soil properties. Therefore, based on the BTUs criteria exposed by Bodin and Morlat (2007), all the vineyards studied, depending on which appellation belong to, should be included in a unique BTU. The excessive fragmentation of a territory in many BTUs is often not economically or practically viable (Carey et al., 2008). In Majorca, this aspect needs to be deeply analyzed, possibly reconsidering the convenience of maintaining more than one appellation in a relatively small viticultural area, where local wine tradition has not been consolidated compared to other Spanish regions.
Soil characterization - Except for vineyard Bi25, in which sediment materials are predominant, all other vineyards showed levels of Total Carbonate and Calcium Carbonate Equivalent ranging from medium to high (Table 2). All pH values ranged from 8.36 and 8.63. These conditions are not limiting for white grapevine varieties, since they do not require much $\mathrm{Fe}^{++}$(Huggett, 2006). Values of electric conductivity were also

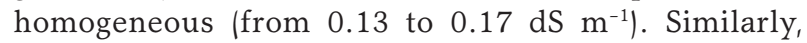
all vineyards had a medium content in Total Organic Matter, with values fluctuating from 1.75 to $2.25 \%$ (Porta et al., 1986). All vineyards showed remarkable high levels of $\mathrm{K}^{+}$, while the content in $\mathrm{Na}^{+}$tended to be low. This suggests that vermiculite and smectite are predominant in the clay fraction in comparison to illite (Huggett, 2006). Parameters such as \% Clay, Useful Water Reserve, Cationic Exchange Capacity, $\mathrm{Mg}^{++}, \mathrm{Ca}^{++}$and Available Phosphorous showed high variability. In such conditions, it is plausible that soil strongly influence performance of vines. In fact, differences in soil parameters are able to produce important variations in vine behaviour even in small and homogeneous viticultural areas (De Andrés-De Prado et al., 2007).

Table 1 - Weather data from both appellations.

\begin{tabular}{|c|c|c|c|c|c|c|c|c|}
\hline \multirow{2}{*}{ Station } & \multicolumn{4}{|c|}{4 year mean (2001-2004) } & \multicolumn{4}{|c|}{2002} \\
\hline & $\mathrm{PTE}(\mathrm{mm})$ & $\mathrm{Ra}(\mathrm{mm})$ & $\operatorname{Tmm}\left({ }^{\circ} \mathrm{C}\right)$ & $\mathrm{ETI}\left({ }^{\circ} \mathrm{C}\right)$ & $\mathrm{PTE}(\mathrm{mm})$ & $\mathrm{Ra}(\mathrm{mm})$ & $\mathrm{Tmm}\left({ }^{\circ} \mathrm{C}\right)$ & $\mathrm{ETI}\left({ }^{\circ} \mathrm{C}\right)$ \\
\hline Th Bi & 658 & & 8.1 & 2295 & 630 & & 8.0 & 2280 \\
\hline Th PL & 640 & & 7.6 & 2301 & 618 & & 7.7 & 2295 \\
\hline Pv Bi 1 & & 236 & & & & 470 & & \\
\hline Pv Bi 2 & & 264 & & & & 455 & & \\
\hline Pv PL 1 & & 226 & & & & 430 & & \\
\hline Pv PL 2 & & 251 & & & & 420 & & \\
\hline
\end{tabular}

$\mathrm{Bi}=$ Binissalem-Mallorca appellation, $\mathrm{PL}=\mathrm{Pla}$ i Llevant appellation. $\mathrm{PTE}=$ potential evapotranspiration (March-September), $\mathrm{Ra}=$ rainfall (March-September), Tmm $=$ mean minimum temperature, ETI = effective thermal integral (March-September) (Amerine and Winkler, 1944). Th = thermometric, $\mathrm{Pv}=$ pluviometric.

Table 2 - Normalization of soil parameters according to different criteria.

\begin{tabular}{|c|c|c|c|c|c|c|}
\hline \multirow{2}{*}{ Parameter } & \multicolumn{5}{|c|}{ Intervals for discrimination of the identified classes } & \multirow{2}{*}{ Criteria } \\
\hline & VL & $\mathrm{L}$ & M & $\mathrm{H}$ & $\mathrm{VH}$ & \\
\hline$\overline{\mathrm{CT}}(\%)$ & & $2-10$ & $10-25$ & $>25$ & & 1 \\
\hline CCE $(\%)$ & & $0-6$ & $6-9$ & $>9$ & & 2 \\
\hline \multirow{2}{*}{$\mathrm{Pa}\left(\mathrm{mg} \mathrm{kg}^{-1}\right)$} & $<6(\mathrm{M} \% \mathrm{cl})$ & 6-12 (M \%cl) & $12-18(\mathrm{M} \% \mathrm{cl})$ & $18-30(\mathrm{M} \% \mathrm{Cl})$ & & \multirow{2}{*}{2} \\
\hline & $<8(\mathrm{H} \% \mathrm{cl})$ & 8-16 (H \%cl) & $16-24(\mathrm{H} \% \mathrm{cl})$ & $24-40(\mathrm{H} \% \mathrm{cl})$ & & \\
\hline \multirow{2}{*}{$\mathrm{K}^{+}\left(\mathrm{mg} \mathrm{kg}^{-1}\right)$} & & & $0.4-0.6(\mathrm{M} \% \mathrm{cl})$ & $0.6-1(\mathrm{M} \% \mathrm{cl})$ & $>1(\mathrm{M} \% \mathrm{cl})$ & \multirow{2}{*}{2} \\
\hline & & & $0.5-0.75(\mathrm{H} \% \mathrm{cl})$ & $0.75-1.25(\mathrm{H} \% \mathrm{cl})$ & $>1.25(\mathrm{H} \% \mathrm{cl})$ & \\
\hline \multirow{2}{*}{$\mathrm{Mg}^{++}\left(\mathrm{mmol}_{\mathrm{c}} \mathrm{kg}^{-1}\right)$} & & 5-14 (M \%cl) & $14-23(\mathrm{M} \% \mathrm{cl})$ & 23-32 (M \%cl) & & \multirow{2}{*}{2} \\
\hline & & 06-15 (H \%cl) & $15-25(\mathrm{H} \% \mathrm{cl})$ & $25-35(\mathrm{H} \% \mathrm{cl})$ & & \\
\hline $\mathrm{Na}^{+}\left(\mathrm{mg} \mathrm{kg}^{-1}\right)$ & $<0.3$ & $0.3-0.6$ & & & & 2 \\
\hline $\mathrm{Ca}^{++}\left(\mathrm{mmol}_{\mathrm{c}} \mathrm{kg}^{-1}\right)$ & & $3.5-10$ & $10-20$ & $20-30$ & & 1 \\
\hline $\mathrm{CEC}\left(\mathrm{mmol}_{\mathrm{c}}^{\mathrm{c}} \mathrm{kg}^{-1}\right)$ & & $60-120$ & $120-250$ & $250-400$ & & 3 \\
\hline \%clay & & & $25-30$ & $30-40$ & $>40$ & 4 \\
\hline UWR (mm) & $<30$ & $30-60$ & $60-100$ & $>100$ & & 5 \\
\hline
\end{tabular}

$\mathrm{VL}=$ very low, $\mathrm{L}=$ low, $\mathrm{M}=$ medium, $\mathrm{H}$ = high; $\mathrm{VH}=$ very high. $\mathrm{CT}=$ total carbonates; $\mathrm{CCE}=$ calcium carbonate equivalent, $\mathrm{Pa}=$ available phosphorous, $\mathrm{K}^{+}=$ exchangeable potassium, $\mathrm{Mg}^{++}=$exchangeable magnesium, $\mathrm{Na}^{+}=$exchangeable sodium, $\mathrm{Ca}^{++}=$exchangeable calcium, $\mathrm{CEC}=$ cationic exchange capacity, UWR = useful water reserve, $\mathrm{cl}=$ clay. 1 = adapted from Villalbí and Vidal (1988), 2 = Consejería de Agricultura y Comercio (1992), $3=$ Porta et al. (1986), $4=$ adapted from López Ritas and López Melida (1990), 5 = adapted from Morlat et al. (2001). 
Principal component analysis of vine parameters - The study of preselected vines by means of principal components allows both to determine which parameters are mostly involved in the total variance of preselection data and to cluster vines according to some specific features (Pérez-Hugalde et al., 2004). During Moll clonal preselection, unfavorable weather conditions occurred in 2002 (Cretazzo et al., 2007). Due to the high summer rainfall, intense attacks by Powery mildew and Botritis cinerea were detected in all vineyards. As a result, production and quality parameters values underwent a considerable interference. Thus, the 2002 data were discarded from this analysis and were not considered in figures and many tables along the text. Principal component analysis of Moll preselection data reveals that the first two factors explain more than $50 \%$ of total variance (Table 3). The first factor is mainly related to production parameters (Yield and Number of Cluster). However, an important relation is also shown in regards to Sugar Content. The second factor is mainly related to Total Tannins and Total Polyphenols Index. Despite the highest coefficient of variation, Pruning Weight does not correlate consistently to any of the first three factors, while Weight of 100 Berries correlates more consistently with the third factor than with the second. Titratable Acidity shows a weak correlation with both the first and second factors.

Previously it was shown that Total Tannins and Total Polyphenols Index variances did not clearly depend on vineyard factor (Cretazzo et al., 2007). Instead, the requirements for candidate clone choice based on Sugar Content and Titratable Acidity levels in berries (Cretazzo et al., 2010b). Thus, Yield, Sugar Content and Titratable Acidity were selected as the most representative vine parameters to perform the following analyses.

Analysis of the factors influencing Yield, Sugar Content and Titratable Acidity - In a first step, the effects produced by vineyard, vintage and virus infections were considered. In a previous study it was shown that vintage, vineyard and grape plant strongly influenced Yield, Sugar Content, Titratable Acidity and other parameters (Cretazzo et al., 2007). However, there was no clear relation between these factors and Total Polyphenols Index or Total Tannins.

In case of close vineyards, the inter-annual weather variations can have a more important effect on vine performance than the differences in weather conditions between vineyards (Ubalde et al., 2007). Factor vineyard can include in its complexity many parameters related to soil, management and microclimate. Cretazzo et al. (2010c) showed that Moll vines presented a high genetic similarity among appellations and vineyards of Majorca. Therefore, it is expected that grape plant effects on vine parameters are more linked to virus infection than to intravarietal genetic variability. Many authors have elucidated the impact of virus infections on grape performance (Rowhani et al., 2005). Cretazzo et al. (2010a) observed that multiple virus infections led to very important Yield reductions in Moll. Therefore, vines were clustered according to the presence of more than one infection by the viruses previously mentioned. Thus, -Multiple Infection refers to both vines that are free of viruses and vines infected by only one virus, while + Multiple Infection indicates vines displaying multiple virus infections.

In the case of GLRaV-1 and 3, the simultaneous detection of both viruses was considered as a simple infection. In all univariate linear models studied, factor vineyard, as well as its interaction with vintage, have a strong effect on each parameter (Table 4). The effect of vintage is also very important. However, in the case of Yield, it is enhanced by the inclusion of the data of year 2002 (four year model), being in the three year model $p<0.05$. Factor Multiple Infection is considerable for Yield but not for Sugar Content and Titratable Acidity. Interaction Multiple Infection*vintage show $p<0.05$ versus Titratable Acidity in both three and four year models, but only in the four year model for Sugar Content. The effect of co-variable Yield is always relevant both for Sugar Content and Titratable Acidity.

Table 3 - Correlation coefficients between production and quality parameters of vines and the first three factors (cp) obtained by principal component analysis. The coefficients of variation (cv) of each original parameter are also showed. Three year data : 2001-2003-2004.

\begin{tabular}{|c|c|c|c|c|}
\hline \multirow{2}{*}{ parameter } & \multicolumn{3}{|c|}{$\mathrm{CC}$} & \multirow{2}{*}{ cv (\%) } \\
\hline & $\mathrm{cp} 1$ & cp 2 & cp 3 & \\
\hline NC & 0.805 & 0.421 & 0.21 & 48.2 \\
\hline Y & 0.828 & 0.254 & 0.304 & 59.1 \\
\hline BW & -0.100 & -0.443 & 0.672 & 22.0 \\
\hline PW & 0.302 & -0.192 & 0.422 & 81.9 \\
\hline SS & -0.664 & 0.026 & 0.416 & 12.6 \\
\hline TA & 0.464 & -0.382 & -0.136 & 26.8 \\
\hline IPT & -0.060 & 0.863 & -0.128 & 49.4 \\
\hline TT & -0.408 & 0.711 & 0.367 & 51.8 \\
\hline$\%$ variance & 28.25 & 23.39 & 13.86 & \\
\hline
\end{tabular}

$\mathrm{NC}=$ number of clusters, $\mathrm{Y}=$ yield per plant $(\mathrm{g}), \mathrm{BW}=$ weight of 100 berries $(\mathrm{g}), \mathrm{PW}=$ pruning weight $(\mathrm{g}), \mathrm{SS}=$ sugar content $\left({ }^{\circ} \mathrm{Brix}\right), \mathrm{TA}=$ titratable acidity $\left(\mathrm{g} \mathrm{L}^{-1}\right)$, IPT = total polyphenols index, $\mathrm{TT}=$ total tannins $\left(\mathrm{g} \mathrm{L}^{-1}\right)$. 
In the three year model for ELISA tested vines, if the co-variable Yield was not considered, the effect of Multiple Infection would be significant (data not shown). This may support the hypothesis of a Sugar Content concentration effect on berry generated by multiple virus infections, which induce Yield decreases (Cretazzo et al., 2010a). No model was suitable to explain the variances of Weight of 100 Berries, Pruning Weight, Total Polyphenols Index or Total Tannins, while parameter Number of Cluster shows patterns similar to parameter Yield (data not shown).

The annual means per vineyard (Table 5) have a general pattern in the case of Yield and Sugar Content, especially regarding 2001, 2003 and 2004. For example, Yield level was regularly low for vineyard PL03, medium for Bi07, Bi17 and PL31, medium-high for Bi01, PL53 and PL62, high for Bi25. The Sugar Content levels were commonly low for vineyards PL03 and PL08, mediumlow for PL46 and PL53, medium for Bi25, high for Bi07 and Bi15. However, a strongly variable behaviour is ascertained in other vineyards (i.e. PL08 for Yield and Bi17 for Sugar Content). No clear outlines are observed for Titratable Acidity.

The important effect of Multiple Infection on Yield is shown in Figure 1. In all vineyards in which data were recorded for both -Multiple Infection and + Multiple Infection vines, the three year mean Yield of the formers is higher, with differences showing $p<0.05$ in five cases. The possible Sugar Content concentration effect is not so evident. In fact, comparisons between -Multiple Infection and + Multiple Infection vines show contradictory results depending on vineyard and, only in Bi17 and PL62, the presence of multiple infections corresponded to significant lower Yield and higher Sugar Content. Finally, Multiple Infection does not show a clear effect on Titratable Acidity.

In a second step, by studying the three year means of each vine, it was pursued to break down the effects of different components contained inside the factor vineyard.

Preliminary one-way ANOVAs (data not shown) indicated that Useful Water Reserve, \% Clay, Cationic
Exchange Capacity and Training System were the parameters mostly involved in the determination of production and quality parameter variances. Vineyard clustering by \% Clay and Cationic Exchange Capacity is the same (Table 2), as expected by observing the positive correlation $(p<0,01)$ between these parameters (Table 6a). In addition, both $\mathrm{Mg}^{++}$and $\mathrm{Ca}^{++}$are highly related to Cationic Exchange Capacity and \% Clay, providing

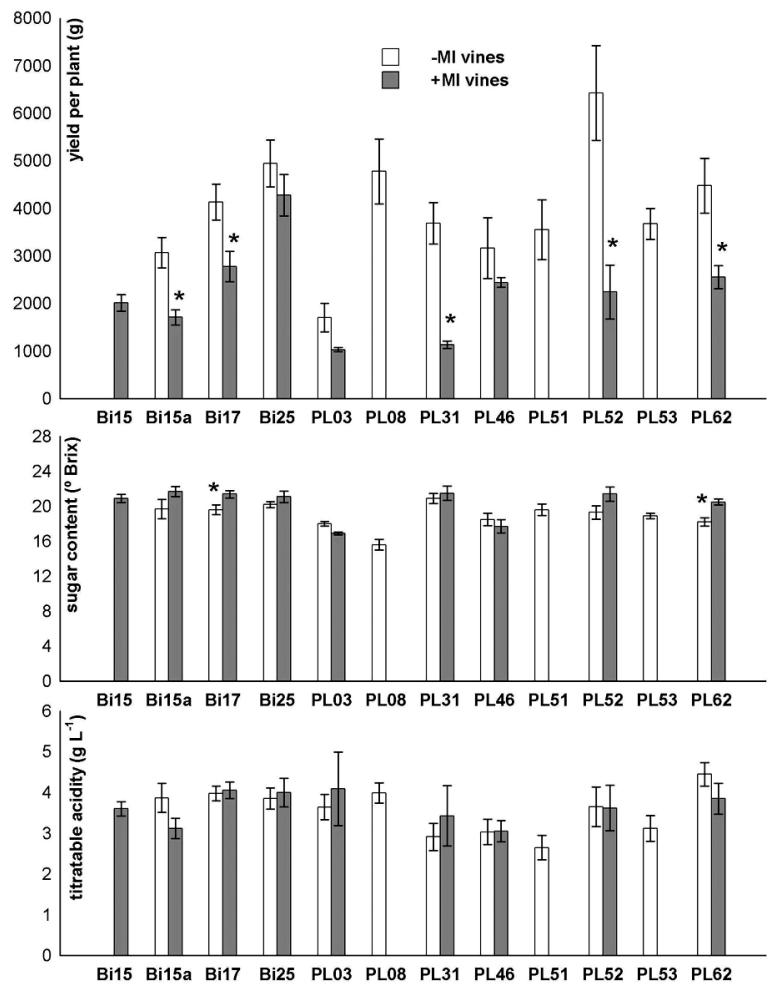

Figure 1 - Effect of the presence/absence of multiple virus infections (MI, see definition in the text) on yield per plant, sugar content and titratable acidity. Three year data: 2001-2003-2004 *indicates differences at ANOVA $(p<0.05)$.

Table 4 - Significance level $(p)$ values obtained by univariate analysis of variance of yield per plant (Y, g), sugar content (SS, ${ }^{\circ} \mathrm{Brix}$ ) and titratable acidity $\left(T A, g \mathrm{~L}^{-1}\right)$. Four models and different effects are studied.

\begin{tabular}{|c|c|c|c|c|c|c|c|c|c|c|c|c|c|}
\hline \multirow{4}{*}{ Effect } & & \multicolumn{12}{|c|}{ Data set } \\
\hline & & \multicolumn{6}{|c|}{ Total vines } & \multicolumn{6}{|c|}{ Vines tested by ELISA } \\
\hline & & \multicolumn{3}{|c|}{4 year data } & \multicolumn{3}{|c|}{3 year data $(-2002)$} & \multicolumn{3}{|c|}{4 year data } & \multicolumn{3}{|c|}{3 year data $(-2002)$} \\
\hline & & $Y$ & SS & TA & $Y$ & SS & TA & $\mathrm{Y}$ & SS & TA & Y & SS & TA \\
\hline \multirow{3}{*}{ Factor } & Vy & 0.000 & 0.000 & 0.000 & 0.003 & 0.000 & 0.000 & 0.000 & 0.000 & 0.000 & 0.000 & 0.000 & 0.000 \\
\hline & $\mathrm{Vi}$ & 0.000 & 0.000 & 0.000 & 0.175 & 0.000 & 0.000 & 0.008 & 0.000 & 0.000 & 0.208 & 0.000 & 0.000 \\
\hline & $\mathrm{Ml}$ & & & & & & & 0.000 & 0.837 & 0.955 & 0.000 & 0.126 & 0.158 \\
\hline \multirow{4}{*}{ Interaction } & $\mathrm{Vy}^{*} \mathrm{Vi}$ & 0.009 & 0.000 & 0.000 & 0.001 & 0.000 & 0.000 & 0.009 & 0.000 & 0.000 & 0.001 & 0.000 & 0.008 \\
\hline & $\mathrm{Vy}^{*} \mathrm{Ml}$ & & & & & & & 0.419 & 0.196 & 0.283 & 0.311 & 0.060 & 0.110 \\
\hline & $\mathrm{Vi}^{*} \mathrm{Ml}$ & & & & & & & 0.594 & 0.031 & 0.000 & 0.431 & 0.725 & 0.000 \\
\hline & $\mathrm{Vy}^{*} \mathrm{Vi}^{*} \mathrm{Ml}$ & & & & & & & 0.999 & 0.442 & 0.553 & 0.996 & 0.331 & 0.192 \\
\hline \multirow[t]{2}{*}{ Co-variable } & $Y$ & & 0.000 & 0.000 & & 0.000 & 0.004 & & 0.002 & 0.005 & & 0.000 & 0.005 \\
\hline & & 0.383 & 0.712 & 0.727 & 0.383 & 0.748 & 0.687 & 0.579 & 0.768 & 0.797 & 0.598 & 0.806 & 0.763 \\
\hline
\end{tabular}

$\mathrm{Vy}=$ vineyard (see Table 5), $\mathrm{Vi}=$ vintage (2001-2002-2003-2004), Ml = presence/absence of multiple virus infections (see definition in the text). 
the same vineyard clustering. Nevertheless, the different component of Cationic Exchange Capacity may be more suitable for future studies focused on their effects on wine aroma (see White et al., 2007). Therefore, only the effect of \% Clay was selected for following analyses.

The principal component plots (Figure 2) show that $\%$ Clay and Training System achieve a clearer separation of vines than Useful Water Reserve. Besides some exceptions, double cordon trained vines and vines grown in very high \% Clay soils discriminate evidently from low vase vines and vines grown in medium \% Clay soils, respectively. High vase trained vines and vines grown in high \% Clay soils show intermediate distributions in the plots. Vine differentiation was also investigated regarding the vineyard age because of its effects on the evolution of soil properties (Marcet et al., 2003). However, no clear pattern is evident. No vine differentiation was noticed either by Available Phosphorous or rootstock (data not shown). In the first case, it may depend on phosphate uptake regulation by symbiotic association between grapevine and mycorrhizal fungi (Huggett, 2006); in the second case, it was probably due to the good affinity between Moll and both 110 Richter and 161-49 rootstocks (Martorell A., personal communication).

The interpretation of the univariant linear models turns much more complicated when several vineyard components are included. On one hand, in a total vine model that assumed \% Clay, Useful Water Reserve and Training System as factors, the formers seemed to have a major influence than Training System on Sugar Content and Titratable Acidity (data not shown). However, only Useful Water Reserve pointed out a main effect on Yield (data not shown). These results may be considered in agreement with a study of Coipel et al. (2006) on Grenache noir, but $\mathrm{R}^{2}$ was very low (0.1362). The model was not able to calculate any interaction. On the other
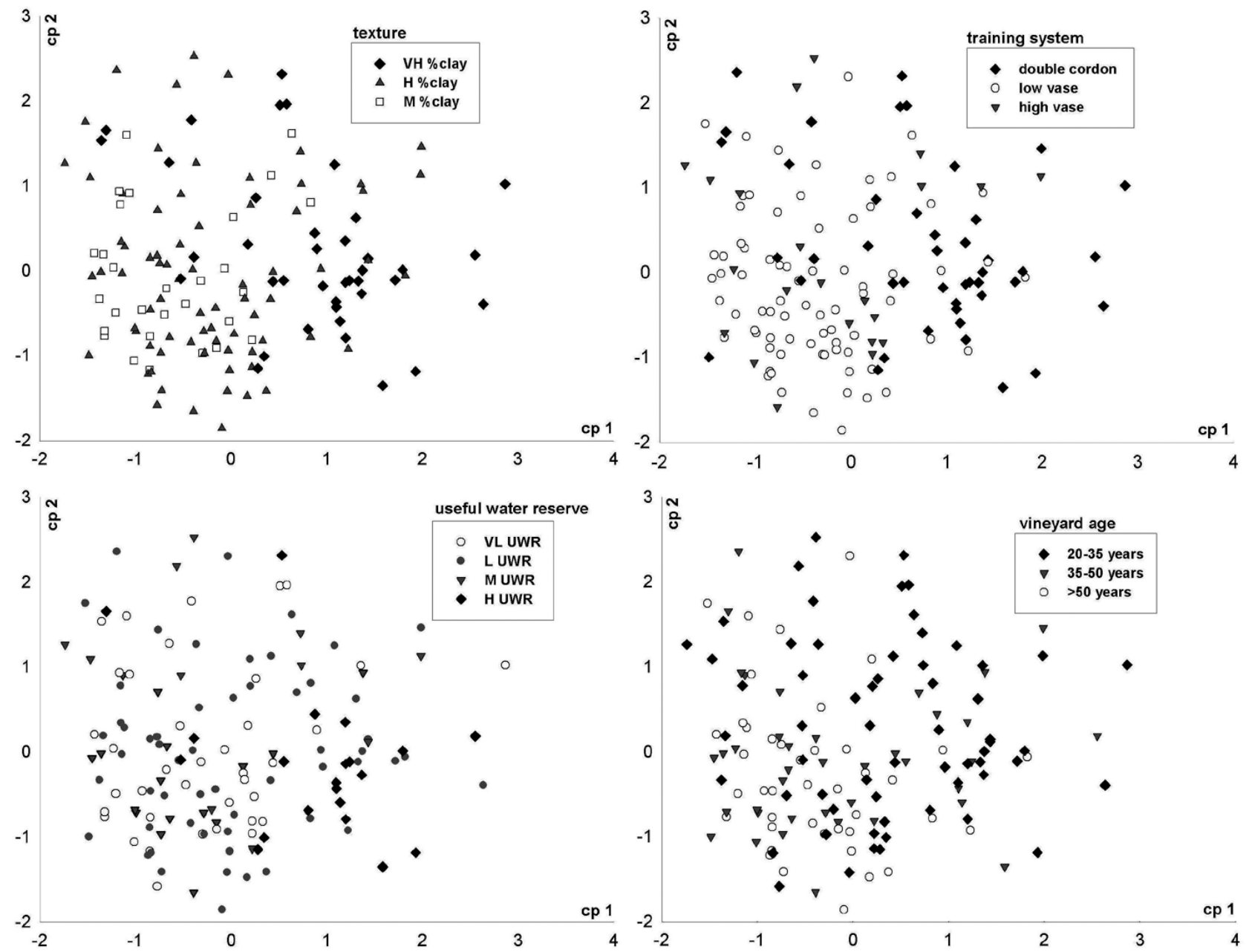

Figure 2 - Principal component plot. Vines are discriminated according to texture, useful water reserve, training system and vineyard age. Three year data: 2001-2003-2004. VL = very low, $\mathrm{L}=$ low, $\mathrm{M}=$ medium, $\mathrm{H}=$ high; $\mathrm{VH}=$ very high. $\mathrm{cp} 1$ and $\mathrm{cp} 2$ are the two first factors obtained by the analysis. 
hand, the three year model for ELISA tested vines (Figure 3) provides more statistically consistent results (much higher $\mathrm{R}^{2}$ ).

The factor Multiple Infection, as well its interaction with Training System, plays a predominant role on Yield variance with respect to each vineyard component that is included in the model. But, the effects of \% Clay and Useful Water Reserve are still the most important on Sugar Content and Titratable Acidity. If the co-variable yield was excluded from both Table 4 and Figure 3 three year ELISA tested vine models, the effect of the factor
Multiple Infection on Sugar Content would show $p<$ 0.05 (data not show). This is another result that supports the concentration effect hypothesis.

Studying separately -Multiple Infection and + Multiple Infection vines, Yield, Sugar Content and Titratable Acidity show different tendencies (Figure 3). Higher \% Clay and double cordon system enhanced Yield in both cases. However, the increase in Yield corresponding to higher potential watering level of substrate (Useful Water Reserve) (see Bodin and Morlat, 2007) is clear in + Multiple Infection vines, but not
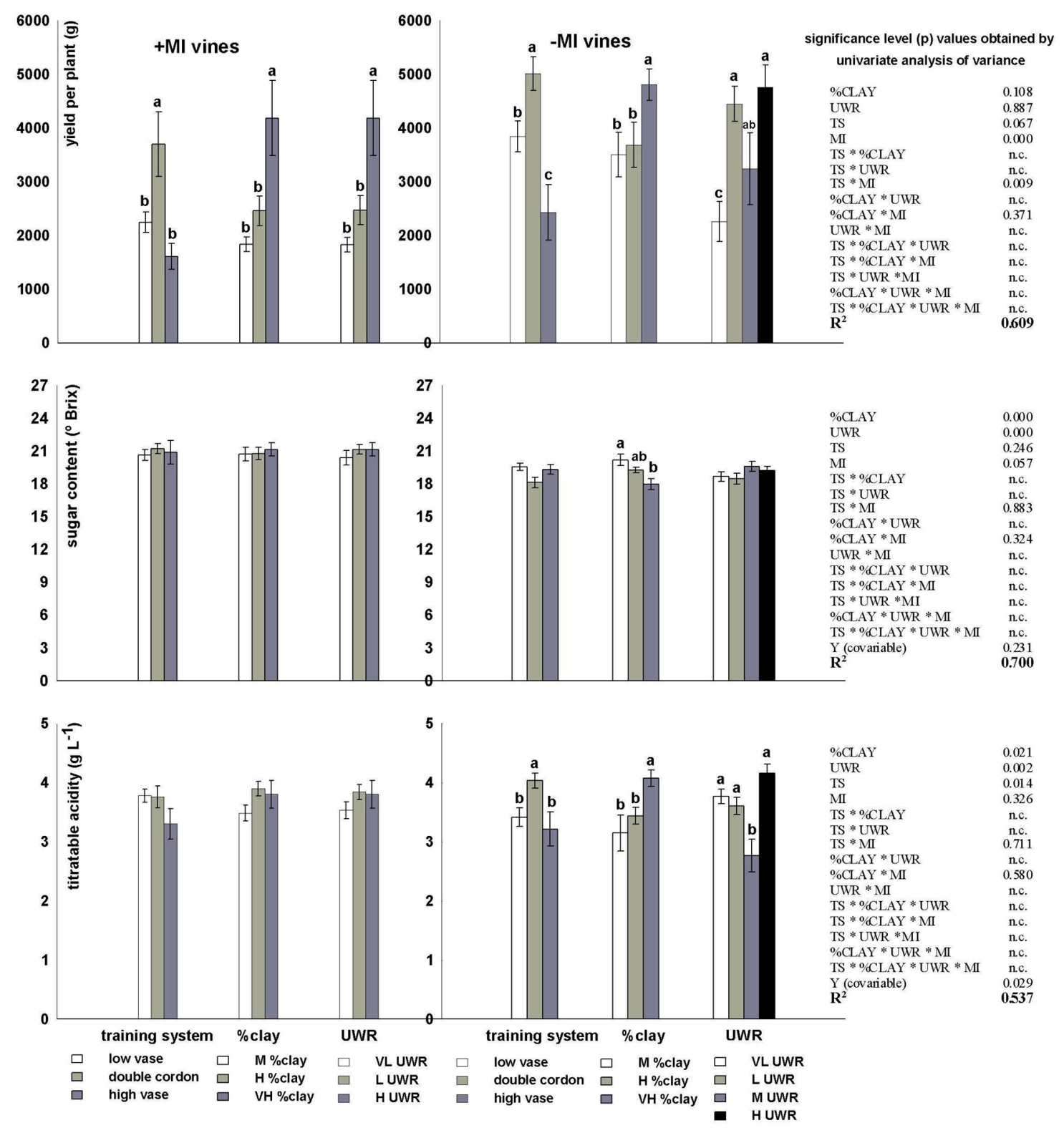

Figure 3 - Effects of training system (TS), texture, useful water reserve (UWR) and presence/absence of multiple virus infections (MI, see definition in the text) on yield per plant, sugar content and titratable acidity. Three year data for ELISA tested vines: 2001-2003-2004. Letters indicate homogeneous groups at Duncan test $(p<0.05)$. $\mathrm{LL}=$ very low, $\mathrm{L}=$ low, $\mathrm{M}=$ medium, $\mathrm{H}=$ high; $\mathrm{VH}=$ very high. $\mathrm{n} . \mathrm{c} .=$ not calculable. 
in -Multiple Infection vines. The effects of Training System, \% Clay and Useful Water Reserve on Sugar Content and Titratable Acidity are not considerable in + Multiple Infection vines. This result can be explained with an intrinsic effect due to the presence of multiple virus infections that overridden the other effects.

In -Multiple Infection vines, Titratable Acidity increases according to Yield for higher level of \% Clay and double cordon system. It is possible that when the interference by virus infections is low, more powerful conditions for vine growth promote higher acidity accumulation in berries. This would be a positive aspect since low Titratable Acidity in berries is often a limiting factor for Moll quality (Cretazzo et al., 2010a). However, no clear relation can be found between Yield and Titratable Acidity; moreover, their

Table 5 - Means and standard errors in different years for yield per plant, sugar content and titratable acidity.

\begin{tabular}{|c|c|c|c|c|c|c|}
\hline$\overline{V y}$ & vines & 2001 & 2002 & 2003 & 2004 & 3 year mean \\
\hline \multicolumn{7}{|c|}{ yield per plant (g) } \\
\hline $\mathrm{Bi} 01$ & 10 & $3716 \pm 538.8^{\text {abcd }}$ & $1235 \pm 254.5$ & $4883 \pm 980.5^{a}$ & n.d. & $3910 \pm 521.9^{a b}$ \\
\hline $\mathrm{Bi} 07$ & 16 & $3051 \pm 471.5^{\text {bcde }}$ & $1481 \pm 495.4$ & $1957 \pm 393.3^{c}$ & $2676 \pm 902.0^{\mathrm{bc}}$ & $2596 \pm 327.5^{\mathrm{bcd}}$ \\
\hline Bi15 & 13 & $1976 \pm 204.6^{\text {de }}$ & $1489 \pm 466.4$ & $1443 \pm 157.4^{c}$ & $2779 \pm 462.6^{b c}$ & $2011 \pm 175.7^{c d}$ \\
\hline Bi15a & 8 & $2125 \pm 290.3^{\text {cde }}$ & nd & $1984 \pm 248.6^{c}$ & $2573 \pm 404.1^{\mathrm{bc}}$ & $2218 \pm 182.3^{\text {cd }}$ \\
\hline Bi17 & 31 & $3478 \pm 243.1^{\text {abcd }}$ & $1454 \pm 284.0$ & $2376 \pm 286.1^{b c}$ & $3039 \pm 478.0^{\mathrm{bc}}$ & $2945 \pm 188.0^{\mathrm{bcd}}$ \\
\hline Bi25 & 11 & $4411 \pm 496.1^{\mathrm{ab}}$ & $3077 \pm 628.0$ & $5181 \pm 498.8^{a}$ & $5004 \pm 850.0^{\mathrm{ab}}$ & $4837 \pm 336.4^{a}$ \\
\hline PL03 & 7 & $1675 \pm 258.2^{\mathrm{e}}$ & nd & $1785 \pm 461.3^{c}$ & $1575 \pm 665.0^{c}$ & $1700 \pm 209.9^{d}$ \\
\hline PL08 & 8 & $2926 \pm 375.9^{\text {bcde }}$ & $3438 \pm 960.8$ & nd & $7244 \pm 662.3^{a}$ & $4777 \pm 683.3^{a}$ \\
\hline PL31 & 8 & $3046 \pm 526.9^{\text {bcde }}$ & $2844 \pm 940.9$ & $2929 \pm 845.2^{\mathrm{bc}}$ & $2160 \pm 920.0^{b c}$ & $2889 \pm 401.4^{\mathrm{bcd}}$ \\
\hline PL46 & 6 & $3327 \pm 523.2^{\text {abcde }}$ & $675 \pm$ n.c. & $1771 \pm 350.1^{c}$ & $3012 \pm 388.3^{b c}$ & $2776 \pm 326.6^{\mathrm{bcd}}$ \\
\hline PL51 & 7 & $3808 \pm 661.2^{\mathrm{abc}}$ & $2177 \pm 294.7$ & nd & $1750 \pm$ n.c. & $3551 \pm 627.7^{a b c}$ \\
\hline PL52 & 5 & $4382 \pm 950.5^{\mathrm{ab}}$ & nd & $2458 \pm 905.0^{\text {bc }}$ & n.d. & $3539 \pm 822.3^{a b c}$ \\
\hline PL53 & 5 & $3761 \pm 428.8^{\mathrm{abc}}$ & $2710 \pm 970.0$ & $4198 \pm 915.5^{\mathrm{ab}}$ & $2990 \pm 170.0^{b c}$ & $3678 \pm 325.8^{\mathrm{ab}}$ \\
\hline PL62 & 15 & $4984 \pm 597.7^{\mathrm{a}}$ & nd & $2491 \pm 374.4^{\mathrm{bc}}$ & $3992 \pm 555.4^{\mathrm{bc}}$ & $3988 \pm 361.9^{\mathrm{ab}}$ \\
\hline \multicolumn{7}{|c|}{ sugar content ('Brix) } \\
\hline $\mathrm{Bi} 01$ & 10 & $19.3 \pm 0.49^{\text {cde }}$ & $20.0 \pm$ n.c. & $19.9 \pm 0.45^{c d}$ & n.d. & $19.4 \pm 0.42^{\mathrm{ab}}$ \\
\hline $\mathrm{Bi} 07$ & 16 & $22.7 \pm 0.36^{a}$ & $17.0 \pm 1.08$ & $22.6 \pm 0.29^{a}$ & $16.2 \pm 0.62^{d}$ & $21.1 \pm 0.54^{a}$ \\
\hline Bi15 & 13 & $22.4 \pm 0.39^{a b}$ & $19.4 \pm 0.81$ & $22.0 \pm 0.43^{a b}$ & $17.4 \pm 0.73^{c d}$ & $20.9 \pm 0.48^{\mathrm{a}}$ \\
\hline Bi15a & 8 & $21.7 \pm 0.82^{\mathrm{ab}}$ & nd & $21.1 \pm 0.44^{\mathrm{abc}}$ & $18.9 \pm 0.67^{b c}$ & $20.7 \pm 0.47^{a}$ \\
\hline Bi17 & 31 & $22.4 \pm 0.25^{\mathrm{ab}}$ & $18.1 \pm 1.08$ & $21.2 \pm 0.23^{\mathrm{abc}}$ & $17.9 \pm 0.39 c d$ & $20.9 \pm 0.26^{a}$ \\
\hline Bi25 & 11 & $20.9 \pm 0.59 \mathrm{bc}$ & $16.3 \pm 0.88$ & $20.3 \pm 0.49^{b c}$ & $20.7 \pm 0.50^{\mathrm{ab}}$ & $20.7 \pm 0.31^{\mathrm{a}}$ \\
\hline PL03 & 7 & $17.2 \pm 0.51^{\dagger}$ & nd & $18.1 \pm 0.30^{d}$ & $18.4 \pm 0.05^{\mathrm{bcd}}$ & $17.7 \pm 0.30^{c}$ \\
\hline PL08 & 8 & $17.2 \pm 0.37^{\dagger}$ & $18.7 \pm 1.02$ & nd & $13.4 \pm 0.43^{e}$ & $15.6 \pm 0.60^{d}$ \\
\hline PL31 & 8 & $20.6 \pm 0.49^{b c d}$ & $16.8 \pm$ n.c. & $20.5 \pm 0.36^{b c}$ & $22.4 \pm 0.40^{a}$ & $20.8 \pm 0.33^{a}$ \\
\hline PL46 & 6 & $18.4 \pm 0.44^{\mathrm{ef}}$ & $20.5 \pm$ n.c. & $19.7 \pm 0.79^{c d}$ & $16.5 \pm 0.24^{d}$ & $18.4 \pm 0.46^{\mathrm{bc}}$ \\
\hline PL51 & 7 & $19.3 \pm 0.70^{\text {cde }}$ & $18.8 \pm 0.40$ & nd & $21.2 \pm$ n.c. & $19.6 \pm 0.66^{a b}$ \\
\hline PL52 & 5 & $21.5 \pm 0.72^{\mathrm{ab}}$ & nd & $20.6 \pm 1.24^{\mathrm{bc}}$ & n.d. & $21.1 \pm 0.66^{a}$ \\
\hline PL53 & 5 & $19.2 \pm 0.21^{\mathrm{de}}$ & $17.8 \pm$ n.c. & $18.3 \pm 0.99^{d}$ & $19.0 \pm 1.00^{\mathrm{bc}}$ & $18.9 \pm 0.31^{b c}$ \\
\hline PL62 & 15 & $18.5 \pm 0.54^{\mathrm{ef}}$ & nd & $20.1 \pm 0.54^{\mathrm{bc}}$ & $18.4 \pm 0.47^{\mathrm{bcd}}$ & $18.9 \pm 0.33^{\mathrm{bc}}$ \\
\hline \multicolumn{7}{|c|}{ titratable acidity $\left(\mathrm{g} \mathrm{L}^{-1}\right)$} \\
\hline$\overline{\mathrm{Bi} 01}$ & 10 & $3.22 \pm 0.25^{\text {bcd }}$ & $4.27 \pm$ n.c. & $4.66 \pm 0.08^{\mathrm{bc}}$ & n.d. & $3.46 \pm 0.26^{\mathrm{abc}}$ \\
\hline $\mathrm{Bi} 07$ & 16 & $2.96 \pm 0.11^{c d}$ & $6.07 \pm 0.41$ & $4.00 \pm 0.13^{\text {cde }}$ & $2.66 \pm 0.22^{\mathrm{bc}}$ & $3.23 \pm 0.13^{\mathrm{bcd}}$ \\
\hline Bi15 & 13 & $2.90 \pm 0.09^{c d}$ & $3.80 \pm 0.43$ & $4.72 \pm 0.23^{b}$ & $3.49 \pm 0.22^{\mathrm{ab}}$ & $3.60 \pm 0.17^{a b c}$ \\
\hline Bi15a & 8 & $3.05 \pm 0.15^{\mathrm{cd}}$ & nd & $4.56 \pm 0.10^{\mathrm{bcd}}$ & $2.74 \pm 0.23^{\mathrm{bc}}$ & $3.41 \pm 0.20^{\mathrm{abc}}$ \\
\hline Bi17 & 31 & $3.08 \pm 0.05^{c d}$ & $5.02 \pm 0.60$ & $4.94 \pm 0.09^{\mathrm{ab}}$ & $3.95 \pm 0.13^{\mathrm{a}}$ & $4.02 \pm 0.11^{\mathrm{a}}$ \\
\hline Bi25 & 11 & $3.41 \pm 0.29 \mathrm{abc}$ & $7.50 \pm 0.86$ & $4.61 \pm 0.15^{\mathrm{bc}}$ & $3.51 \pm 0.36^{\mathrm{ab}}$ & $3.85 \pm 0.19 \mathrm{abc}$ \\
\hline PL03 & 7 & $3.33 \pm 0.20^{\mathrm{bc}}$ & nd & $4.79 \pm 0.26^{b}$ & $2.89 \pm 0.64^{\mathrm{abc}}$ & $3.79 \pm 0.26 \mathrm{abc}$ \\
\hline PL08 & 8 & $4.01 \pm 0.27^{a}$ & $7.05 \pm 0.18$ & nd & $3.96 \pm 0.48^{a}$ & $3.99 \pm 0.25^{\mathrm{ab}}$ \\
\hline PL31 & 8 & $2.59 \pm 0.20^{d}$ & $5.50 \pm$ n.c. & $3.90 \pm 0.17^{\mathrm{de}}$ & $3.41 \pm 0.84^{\mathrm{ab}}$ & $3.14 \pm 0.23^{c d}$ \\
\hline PL46 & 6 & $3.17 \pm 0.27^{\mathrm{bcd}}$ & $4.35 \pm$ n.c. & $3.44 \pm 0.29 \mathrm{e}$ & $2.55 \pm 0.29^{b c}$ & $3.11 \pm 0.18^{\mathrm{cd}}$ \\
\hline PL51 & 7 & $2.78 \pm 0.30^{c d}$ & $5.30 \pm 0.00$ & nd & $1.72 \pm$ n.c. & $2.65 \pm 0.30^{d}$ \\
\hline PL52 & 5 & $2.99 \pm 0.23^{\mathrm{cd}}$ & nd & $4.50 \pm 0.05^{\mathrm{bcd}}$ & n.d. & $3.66 \pm 0.29 \mathrm{abc}$ \\
\hline PL53 & 5 & $3.02 \pm 0.22^{\mathrm{cd}}$ & $5.32 \pm$ n.c. & $4.36 \pm 0.07 \mathrm{bcd}$ & $2.10 \pm 0.07^{c}$ & $3.12 \pm 0.32^{\mathrm{cd}}$ \\
\hline PL62 & 15 & $3.82 \pm 0.25^{\mathrm{ab}}$ & nd & $5.49 \pm 0.16^{\mathrm{a}}$ & $3.21 \pm 0.24^{\mathrm{abc}}$ & $4.15 \pm 0.20^{\mathrm{a}}$ \\
\hline
\end{tabular}

$\mathrm{Vy}=$ vineyard, $\mathrm{Bi}=$ Binissalem-Mallorca appellation, $\mathrm{PL}=\mathrm{Pla}$ i Llevant appellation. Letters indicate homogeneous groups at Duncan test $(p<0.05)$. n.c. $=$ not calculable, n.d. = no data avalaible. 
Table 6 - Pearson's correlation matrix between: a) soil parameters; b) production and quality parameters. Three year data in section b: 20012003-2004.

\begin{tabular}{|c|c|c|c|c|c|c|c|c|c|}
\hline & CT & CCE & $\mathrm{Pa}$ & CEC & $\mathrm{K}^{+}$ & $\mathrm{Ca}^{++}$ & $\mathrm{Mg}^{++}$ & $\mathrm{Na}^{+}$ & \%clay \\
\hline$\overline{\mathrm{CCE}}$ & 0.842 ** & & & & & & & & \\
\hline $\mathrm{Pa}$ & 0.238 & 0.412 & & & & & & & \\
\hline CEC & -0.434 & -0.137 & 0.033 & & & & a & & \\
\hline $\mathrm{K}^{+}$ & $-0.639^{\star}$ & -0.32 & 0.427 & $0.588^{*}$ & & & & & \\
\hline $\mathrm{Ca}^{++}$ & $-0.572^{*}$ & -0.432 & -0.089 & $0.782^{* *}$ & 0.408 & & & & \\
\hline $\mathrm{Mg}^{++}$ & -0.239 & 0.054 & 0.102 & $0.816^{* *}$ & 0.323 & $0.600^{*}$ & & & \\
\hline $\mathrm{Na}^{+}$ & -0.279 & -0.096 & 0.064 & 0.444 & $0.560^{*}$ & -0.044 & 0.306 & & \\
\hline \%clay & -0.482 & -0.293 & 0.171 & $0.883^{* *}$ & $0.738^{* *}$ & $0.737^{* *}$ & $0.634^{*}$ & 0.457 & \\
\hline \multirow[t]{2}{*}{ UWR } & -0.425 & -0.379 & 0.051 & 0.515 & 0.506 & $0.606^{*}$ & 0.279 & 0.282 & $0.689^{* *}$ \\
\hline & $\mathrm{NC}$ & $Y$ & BW & PW & SS & $\mathrm{TA}$ & IPT & & \\
\hline Y & $0.729^{* *}$ & & & & & & & & \\
\hline BW & 0.124 & 0.056 & & & & & & & \\
\hline PW & 0.162 & 0.143 & 0.071 & & & & $b$ & & \\
\hline SS & $-0.495^{* *}$ & $-0.417^{* *}$ & -0.109 & -0.029 & & & & & \\
\hline TA & 0.044 & 0.073 & 0.024 & 0.077 & -0.133 & & & & \\
\hline IPT & 0.205 & 0.128 & -0.142 & 0.100 & -0.103 & -0.045 & & & \\
\hline TT & $-0.224^{*}$ & $-0.256^{*}$ & 0.063 & -0.137 & $0.267^{\circ}$ & 0.038 & $-0.402^{* *}$ & & \\
\hline
\end{tabular}

For abbreviations see Tables 2 and $3 .{ }^{*}=p<0.05,{ }^{* *}=p<0.01$

correlation shows $p>0.05$ (Table 6b). In -Multiple Infection vines, \% Clay influences Sugar Content levels in berries $(p<0.05)$. Thus, in absence of multiple infections, according to \% Clay, the more production, the less sugar content.

Despite these results and the supported hypothesis of a Sugar Content concentration effect induced by virus infections, the relationship between Sugar Content and Yield is not so clear yet. Although their correlation shows $p<0.01$, the value is lower than 0.5 (Table 6b); their regression $\left({ }^{\circ}\right.$ Brix $=21.189-0.00056$ g) also shows $p<0.05$, but both slope and $R^{2}(0.1362)$ are very low.

In general, vineyard PL03 showed low levels for both Yield and Sugar Content every year, while Bi07 showed the highest Sugar Content mean in 2001, the most productive year for this vineyard (Table 5). Therefore, higher production levels do not necessarily correspond to lower levels in quality parameters in Moll. Thus, further studies are required to identify the most suitable management techniques in order to optimize berry sugar content and acidity in high production conditions.

Limitations and main evidence - The models studied are not balanced. In fact, the number of vines was different between vineyards, not all vines were evaluated each year and ELISA was performed on little more than $50 \%$ of total vines, being vineyards $\mathrm{Bi} 01$ and $\mathrm{Bi} 07$ not tested for virus infections. In addition, in clonal preselection programs, it is not possible to design an experiment in which all factor combinations are measured. As a consequence, the lack of enough degrees of freedom for statistic analyses did not allow calculating the effects of several factors in more complex models and not all interactions could be determined (Figure 3).
It is plausible that some random factors also influenced the variance of vine parameters: (i) the microclimate in each vineyard (Deloire et al., 2005), (ii) the gradients in soil properties within the same vineyard (Trought et al., 2008), (iii) the goodness of farmers which can led to different effectiveness in vineyard management (White et al., 2007), (iv) the occurrence of diseases, pests and/or other virus infections etc. Thus, taking into account all these considerations, this study can be defined as a preliminary base to develop further and more advanced researches. However, in spite of that, clonal preselection programs in Majorca have produced a great database, which has allowed realizing that multiple virus infections strongly influence Moll performance, especially its production potential and, obviously, wine characteristics. This may conceal implications on "wine tipicity" and, possibly on terroir.

According to the last definition by OIV (Resolution OIV/VITI 333/2010, available on OIV webpage), Vitivinicultural terroir is a concept which refers to an area in which collective knowledge of the interactions between the identifiable physical and biological environment and applied vitivinicultural practices develops, providing distinctive characteristics for the products originating from this area. Terroir includes specific soil, topography, climate, landscape characteristics and biodiversity features. Apparently, grapevine viruses are not contemplated in the concept of terroir and no study approaching on a possible interference by viruses on terroir is available. But, an attentive analysis of the OIV definition suggests that viruses could play a role. In fact, it is not a wrong to say that viruses belong to biological environment and their interaction with grapevine genomes may modify biodiversity features. Therefore, 
considering that such a situation of endemic virus infections is very common in many European autochthonous varieties and that virus incidence is variable among viticultural areas (see Cretazzo et al., 2010b), a possible interference by grapevine viruses on terroir should be further studied.

Attached 1 - Virus tests by ELISA per each vine included in the study.

\begin{tabular}{|c|c|c|c|c|c|}
\hline $\begin{array}{l}\text { Vineyard } \\
\end{array}$ & Vine & GFLV & GFkV & GLRaV-1 & GLRaV-3 \\
\hline \multirow{10}{*}{ Bi.01 } & P.Bi.01.01 & - & - & - & - \\
\hline & P.Bi.01.02 & - & - & - & - \\
\hline & P.Bi.01.03 & - & - & - & - \\
\hline & P.Bi.01.04 & - & - & - & - \\
\hline & P.Bi.01.05 & - & - & - & - \\
\hline & P.Bi.01.06 & - & - & - & - \\
\hline & P.Bi.01.07 & - & - & - & - \\
\hline & P.Bi.01.08 & - & - & - & - \\
\hline & P.Bi.01.09 & - & - & - & - \\
\hline & P.Bi.01.10 & - & - & - & - \\
\hline \multirow{14}{*}{ Bi.07 } & P.Bi.07.01 & - & - & - & - \\
\hline & P.Bi.07.02 & - & - & - & - \\
\hline & P.Bi.07.04 & - & - & - & - \\
\hline & P.Bi.07.05 & - & - & - & - \\
\hline & P.Bi.07.06 & - & - & - & - \\
\hline & P.Bi.07.08 & - & - & - & - \\
\hline & P.Bi.07.09 & - & - & - & - \\
\hline & P.Bi.07.10 & - & - & - & - \\
\hline & P.Bi.07.11 & - & - & - & - \\
\hline & P.Bi.07.12 & - & - & - & - \\
\hline & P.Bi.07.13 & - & - & - & - \\
\hline & P.Bi.07.14 & - & - & - & - \\
\hline & P.Bi.07.20 & - & - & - & - \\
\hline & P.Bi.07.21 & - & - & - & - \\
\hline \multirow{13}{*}{ Bi.15 } & P.Bi.15.02 & 0 & 1 & 1 & 1 \\
\hline & P.Bi.15.03 & 0 & 1 & 1 & 1 \\
\hline & P.Bi.15.04 & 1 & 1 & 1 & 1 \\
\hline & P.Bi.15.05 & 1 & 0 & 1 & 1 \\
\hline & P.Bi.15.06 & 1 & 1 & 1 & 1 \\
\hline & P.Bi.15.07 & - & - & - & - \\
\hline & P.Bi.15.08 & 1 & 1 & 1 & 1 \\
\hline & P.Bi.15.09 & 0 & 1 & 1 & 1 \\
\hline & P.Bi.15.10 & 0 & 1 & 1 & 1 \\
\hline & P.Bi.15.12 & - & - & - & - \\
\hline & P.Bi.15.13 & - & - & - & - \\
\hline & P.Bi.15.14 & 1 & 0 & 1 & 1 \\
\hline & P.Bi.15.15 & - & - & - & - \\
\hline \multirow{10}{*}{ Bi.17 } & P.Bi.17.01 & - & - & - & - \\
\hline & P.Bi.17.02 & 0 & 0 & 0 & 1 \\
\hline & P.Bi.17.03 & 1 & 0 & 0 & 1 \\
\hline & P.Bi.17.04 & 1 & 0 & 1 & 1 \\
\hline & P.Bi.17.07 & 0 & 0 & 0 & 1 \\
\hline & P.Bi.17.08 & 1 & 1 & 1 & 1 \\
\hline & P.Bi.17.09 & - & - & - & - \\
\hline & P.Bi.17.10 & 0 & 0 & 1 & 1 \\
\hline & P.Bi.17.11 & - & - & - & - \\
\hline & P.Bi.17.12 & 1 & 0 & 1 & 1 \\
\hline
\end{tabular}

\section{Conclusions}

Moll variety demonstrates a great viticultural and oenological potential. Under conditions that enhance its production, sugar accumulation in berries and acidity did not decrease. Negative effects of grapevine virus infections on Moll performance are evident, as well as it is not an utopia to hypothesize a quite distortion by viruses on Moll terroir.

\begin{tabular}{|c|c|c|c|c|c|}
\hline & P.Bi.17.13 & - & - & - & - \\
\hline & P.Bi.17.14 & - & - & - & - \\
\hline & P.Bi.17.15 & - & - & - & - \\
\hline & P.Bi.17.16 & 0 & 0 & 1 & 1 \\
\hline & P.Bi.17.17 & 0 & 0 & 1 & 1 \\
\hline & P.Bi.17.18 & - & - & - & - \\
\hline & P.Bi.17.19 & - & - & - & - \\
\hline & P.Bi.17.20 & 1 & 0 & 1 & 1 \\
\hline & P.Bi.17.21 & - & - & - & - \\
\hline & P.Bi.17.22 & 1 & 0 & 1 & 1 \\
\hline & P.Bi.17.23 & - & - & - & - \\
\hline & P.Bi.17.24 & 1 & 0 & 1 & 1 \\
\hline & P.Bi.17.25 & 1 & 0 & 0 & 1 \\
\hline & P.Bi.17.26 & 0 & 0 & 1 & 1 \\
\hline & P.Bi.17.27 & 0 & 0 & 1 & 1 \\
\hline & P.Bi.17.28 & - & - & - & - \\
\hline & P.Bi.17.29 & - & - & - & - \\
\hline & P.Bi.17.30 & - & - & - & - \\
\hline & P.Bi.17.31 & - & - & - & - \\
\hline & P.Bi.17.40 & - & - & - & - \\
\hline & P.Bi.17.41 & - & - & - & - \\
\hline & P.Bi.25.01 & 0 & 0 & 0 & 0 \\
\hline & P.Bi.25.03 & 0 & 0 & 0 & 0 \\
\hline & P.Bi.25.04 & 0 & 0 & 1 & 1 \\
\hline & P.Bi.25.05 & - & - & - & - \\
\hline Bi.25 & P.Bi.25.06 & 1 & 0 & 0 & 1 \\
\hline & P.Bi.25.07 & 1 & 0 & 0 & 0 \\
\hline & P.Bi.25.08 & 1 & 0 & 1 & 1 \\
\hline & P.Bi.25.09 & 1 & 0 & 0 & 0 \\
\hline & P.Bi.25.10 & 1 & 0 & 0 & 0 \\
\hline & P.Bi.25.20 & 1 & 0 & 0 & 1 \\
\hline & P.Bi.15.11 & 0 & 1 & 1 & 1 \\
\hline & P.Bi.15.16 & 0 & 1 & 1 & 1 \\
\hline & P.Bi.15.17 & 0 & 1 & 1 & 0 \\
\hline Bi.15 & P.Bi.15.18 & - & - & - & - \\
\hline & P.Bi.15.19 & 0 & 1 & 0 & 0 \\
\hline & P.Bi.15.20 & 0 & 1 & 0 & 0 \\
\hline & P.Bi.15.21 & 0 & 1 & 1 & 1 \\
\hline & P.Bi.15.22 & - & - & - & - \\
\hline & P.PI.03.01 & - & - & - & - \\
\hline & P.PI.03.02 & 0 & 0 & 0 & 0 \\
\hline & P.PI.03.03 & 0 & 1 & 0 & 0 \\
\hline PL.03 & P.PI.03.04 & 0 & 0 & 0 & 0 \\
\hline & P.PI.03.05 & - & - & - & - \\
\hline & P.PI.03.06 & 1 & 0 & 1 & 1 \\
\hline & P.PI.03.07 & - & - & - & - \\
\hline
\end{tabular}


Attached 1 - Continuation.

\begin{tabular}{|c|c|c|c|c|c|}
\hline \multirow{8}{*}{ PL.08 } & P.PI.08.01 & 0 & 0 & 0 & 1 \\
\hline & P.PI.08.02 & 0 & 0 & 0 & 1 \\
\hline & P.PI.08.03 & 0 & 0 & 0 & 1 \\
\hline & P.PI.08.04 & 0 & 0 & 0 & 1 \\
\hline & P.PI.08.05 & 0 & 0 & 0 & 1 \\
\hline & P.PI.08.06 & 0 & 0 & 0 & 1 \\
\hline & P.PI.08.07 & - & - & - & - \\
\hline & P.PI.08.08 & - & - & - & - \\
\hline \multirow{8}{*}{ PL.31 } & P.PI.31.01 & 1 & 0 & 0 & 1 \\
\hline & P.PI.31.02 & 1 & 0 & 0 & 0 \\
\hline & P.PI.31.03 & 0 & 0 & 0 & 0 \\
\hline & P.PI.31.04 & 0 & 0 & 0 & 0 \\
\hline & P.PI.31.05 & - & - & - & - \\
\hline & P.PI.31.06 & - & - & - & - \\
\hline & P.PI.31.07 & 1 & 0 & 0 & 0 \\
\hline & P.PI.31.08 & - & - & - & - \\
\hline \multirow{6}{*}{ PL:46 } & P.PI.46.01 & 1 & 1 & 0 & 0 \\
\hline & P.PI.46.02 & - & - & - & - \\
\hline & P.PI.46.03 & - & - & - & - \\
\hline & P.PI.46.05 & - & - & - & - \\
\hline & P.PI.46.06 & 0 & 0 & 0 & 1 \\
\hline & P.PI.46.07 & 0 & 1 & 0 & 0 \\
\hline \multirow{7}{*}{ PL.51 } & P.PI.51.01 & 0 & 0 & 0 & 0 \\
\hline & P.PI.51.02 & 1 & 0 & 0 & 0 \\
\hline & P.PI.51.03 & 1 & 0 & 0 & 0 \\
\hline & P.PI.51.04 & - & - & - & - \\
\hline & P.PI.51.05 & - & - & - & - \\
\hline & P.PI.51.06 & - & - & - & - \\
\hline & P.PI.51.07 & - & - & - & - \\
\hline \multirow{5}{*}{ PL:52 } & P.PI.52.01 & - & - & - & - \\
\hline & P.PI.52.02 & 0 & 0 & 0 & 1 \\
\hline & P.PI.52.03 & 0 & 0 & 0 & 0 \\
\hline & P.PI.52.04 & 1 & 0 & 0 & 1 \\
\hline & P.PI.52.05 & 1 & 0 & 0 & 1 \\
\hline \multirow{5}{*}{ PL.53 } & P.PI.53.01 & 0 & 0 & 1 & 0 \\
\hline & P.PI.53.02 & 0 & 0 & 0 & 1 \\
\hline & P.PI.53.03 & 0 & 0 & 0 & 1 \\
\hline & P.PI.53.04 & - & - & - & - \\
\hline & P.PI.53.05 & - & - & - & - \\
\hline \multirow{15}{*}{ PL.62 } & P.PI.62.01 & - & - & - & - \\
\hline & P.PI.62.02 & - & - & - & - \\
\hline & P.PI.62.03 & 1 & 0 & 0 & 0 \\
\hline & P.PI.62.04 & - & - & - & - \\
\hline & P.PI.62.05 & 1 & 1 & 0 & 1 \\
\hline & P.PI.62.06 & 1 & 1 & 0 & 0 \\
\hline & P.PI.62.07 & 0 & 0 & 0 & 0 \\
\hline & P.PI.62.08 & 1 & 0 & 0 & 0 \\
\hline & P.PI.62.09 & 1 & 0 & 0 & 0 \\
\hline & P.PI.62.10 & 0 & 0 & 0 & 0 \\
\hline & P.PI.62.11 & - & - & - & - \\
\hline & P.PI.62.12 & 0 & 0 & 0 & 0 \\
\hline & P.PI.62.13 & - & - & - & - \\
\hline & P.PI.62.14 & - & - & - & - \\
\hline & P.PI.62.15 & 1 & 1 & 0 & 0 \\
\hline
\end{tabular}

$\overline{\mathrm{Bi}}=$ Binissalem-Mallorca appellation, $\mathrm{PL}=$ Pla i Llevant appellation, $\mathrm{P}=$ Prensal blanc (a local synonymous of Moll). $0=$ negative test, $1=$ positive test, - = no test.

\section{Acknowledgements}

The INIA (Instituto Nacional de Investigación y Tecnología Agraria y Alimentaria) (Spain), made possible the researches necessary to achieve this study by funding the project "Caracterización y conservación de variedades locales mayoritarias de vid de las Islas Baleares. Análisis de los principales factores que determinan la calidad de cosecha" (RTA2008-00085-C02-01). We are very grateful to the staff of soil analyses laboratory of the IBAB S.A. We also give thanks to Profs. Sigfredo Fuentes and Mike McCahon for their English corrections. Finally, we would acknowledge Miss Ronisse Secco for her Portuguese translation.

\section{References}

Amerine, M.A.; Winkler, A.J. 1944. Composition and quality of must and wines of California grapes. Hilgardia, 57: 493-675.

Blake, G.R; Hartge, K.H. 1986. Bulk density. p. 363-375. In: Methods of soil analysis. . 2.ed. Soil Science Society of America, Madison, WI, USA.

Bodin, R.; Morlat, R. 2007. Characterization of viticultural terroirs using a simple field model based on soil depth. I. Validation of the water supply regime, phenology and vine vigour, in the Anjou vineyard (France). Plant and Soil 281: 37-54.

Bower, C.A.; Reitemeier, R.F.; Fireman, M. 1952. Exchangeable cation analysis of saline and alkaline soils. Soil Science 73: 251261.

Bremmer, J.M.; Mulvaney, C.S. 1986. Nitrogen-Total. p. 595624. In: Methods of soil analysis. 2.ed. Soil Science Society of America, Madison, WI, USA.

Campo, E.; Do, B.V.; Ferreira, V.; Valentini, D. 2008. Aroma properties of young Spanish monovarietal white wines: a study using sorting task, list of terms and frequency of citation. Australian Journal of Grape and Wine Research 14: 104-115

Carey, V.A.; Saayaman, D.; Archer, E.; Barbeau, G.; Wallace, M. 2008. Viticultural terroirs in Stellenbosch, South Africa. I. The identification of natural terroir units. Journal Internationale des Science de la Vigne et du Vin 42: 169-183.

Coipel, J.; Rodriguez-Lovelle, B.; Sipp, C.; Van Leeuwen, C.. 2006. Terroir effect, as a result of environmental stress, depends more on soil depth than on soil type (Vitis vinifera L. cv. Grenache noir, Côtes du Rhône, France, 2000). Journal Internationale des Science de la Vigne et du Vin 40: 177-185.

Consejería de Agricultura y Comercio. Junta de Extremadura. 1992. Soil, Leaf and Watering Analyses Interpretation: Fertilization Advices; Basic Rules. 280 p. Mundiprensa, Madrid, Spain. (in Spanish, with abstract in English)

Cretazzo, E.; Padilla, C.; Carambula, C.; Hita, I.; Salmerón, E.; Cifre, J. 2010a. Comparison of the effects of different virus infections on performance of three Majorcan grapevine cultivars in field conditions. Annals of Applied Biology 156: 1-12.

Cretazzo, E.; Tomás, M.; Padilla, C.; Rosselló, J.; Medrano, H.; Padilla, V.; Cifre, J. 2010b. Incidence of virus infection in old vineyards of local grapevine varieties from Majorca: implications for clonal selection strategies. Spanish Journal of Agricultural Research 8: 409-418. 
Cretazzo, E.; Meneghetti, S.; De Andrés, M.T.; Gaforio, L.; Frare, E.; Cifre, J. 2010c. Clone differentiation and varietal identification by means of SSR, AFLP, SAMPL and M-AFLP in order to assess the clonal selection of grapevine: the case study of Manto Negro, Callet and Moll, autochthonous cultivars of Majorca. Annals of Applied Biology 157: 213-227.

Cretazzo, E.; Rosselló, J.; Carambula, C.; Moreno, M.T.; Tomas, M.; Riera, D.; Pou, A.; Martorell, A.; Medrano, H.; Cifre, J. 2007. Clonal Selection of the main Majorcan grapevine varieties: environmental effects on production and quality parameters in preselected plants. p. 1262 -1272. Proceedings of the GESCO Meeting 15. Porec, Croatia.

De Andrés-De Prado, R.; Yuste-Rojas, M.; Sort, X.; AndrésLacueva, C.; Torres, M.; Lamuela-Raventós, R.M. 2007. Effect of soil type on wines produced from Vitis vinifera L. cv. Grenache in commercial vineyards. Journal of Agricultural and Food Chemistry 55: 779-786.

Deloire, A.; Vaudour, E.; Carey, V.; Bonnardot, V.; Van Leeuwen, C. 2005. Grapevine responses to terroir: a global approach. Journal Internationale des Science de la Vigne et du Vin 39: 149-162.

Failla, O.; Brancadoro, L.; Scienza, A. 2007. Actual and possible impact of grapevine local varieties on viticulture: the Italian case. Acta Horticulturae 754: 31-38.

Farrús, E.; Viete, I.; Calafat, A.; Vadell, J.; 2002. Topographic sequences of soils developed on two contrasting lithologies: loamy and hard limestones. Butlletí de la Societat d'Història Natural de les Balears 45: 22-43 (in Spanish, with abstract in English).

Gee, G.W.; Bauder, J.W. 1986. Particle-size analysis. p. 383-411. In: Methods of soil analysis. 2.ed. Soil Science Society of America, Madison, WI, USA.

Hancock, J. 1999. Feature review-"Terroir: the role of geology, climate, and culture in the making of french wines" by J.E. Wilson 1998. Journal of Wine Research 10: 43-49

Huggett, J.M. 2006. Geology and wine: a review. Proceedings of the Geologists' Association 117: 239-247.

López Ritas, J.; López Melida, J. 1990. Soil and Plant Diagnosis: Field and Laboratory Methods. 4.ed. 363 p. Mundiprensa, Madrid, Spain. (in Spanish, with abstract in English)

Marcet, P.; Andrade, L.; Amoedo, R.; Fernández E. 2003. Limiting factors for Vitis vinifera L., Albariño variety production in soils dedicated to the vineyard single-crop system. Journal Internationale des Science de la Vigne et du Vin 37: 31-38.
Miller, R.W.; Gardiner, D.T. 1998. Soils in Our Environment. 8ed. 736 p. R.W. Miller, Prentice Hall, Upper Saddle River, NJ, USA.

Morlat, R.; Barbeau, G.; Asselin, C. 2001. Natural and human factors involved in French viticultural terroirs: study and evaluation methods. Etudes et Recherches des Systèmes Agraires et du Développement 32: 111-127 (in French, with abstract in English)

Olsen, S.R.; Cole, C.V.; Watanabe, F.S.; Dean, L.A. 1954. Estimation of available phosphorus in soil by extraction with sodium bicarbonate. p. 1-19. In: United States Department of Agriculture, Washington DC, USA. (Circular, 939).

Pérez-Hugalde, C.; Júdez, L.; Litago, J.; Yuste, J.; Fuentes-Pila, J. 2004. Statistical procedure for clonal preselection of Vitis vinifera L. cv. Tempranillo in the Duero Valley, Spain. American Journal of Enology and Viticulture 55: 335-345.

Porta, J.; López-Acevedo, M.; Rodríguez, R. 1986. Techniques and Experiments in Edaphology $=$ Técnicas y Experimentos en Edafología. 282 p. Barcelona, Spain. (in Spanish)

Rowell, D.L. 1996. Soil Science: Methods and Applications . 3.ed. 350 p. Longman, Essex, UK.

Rowhani, A.; Uyemoto, J.K.; Golino, D.; Martelli, G.P. 2005. Pathogen testing and certification of Vitis and Prunus species. Annual Review of Phytopathology 43: 261-278.

Smart, R.E. 1985. Principles of grapevine canopy microclimate manipulation with implications for yield and quality: a review. American Journal of Enology and Viticulture 36: 230-239.

Trought, M.C.T.; Dixon, R.; Mills, T.; Greven, M.; Agnew, R.; Mauk, J.; Praat, J.-P. 2008. The impact of differences in soil texture within a vineyard on vine vigour, vine earliness and juice composition. Journal Internationale des Science de la Vigne et du Vin 42: 67-72.

Ubalde, J.M.; Sort, X.; Poch, R.M.; Porta, M. 2007. Influence of edapho-climatic factors on grape quality in Conca de Baberà vineyards (Catalonia, Spain). Journal Internationale des Science de la Vigne et du Vin 41: 33-41.

Villalbí, I.; Vidal, M. 1988. Soil and Leaf Analyses: Interpretation and Fertilization $=$ Anàlisi de Sòls i Foliars: Interpretació i Fertilització. 201 p. Fundación Caixa de Pensions, Barcelona, Spain. (in Spanish)

White, R.; Balachandra, L.; Edis, R.; Chen, D. 2007. The soil component of terroir. Journal Internationale des Science de la Vigne et du Vin 41: 9-18. 